\title{
ANALISIS PROMOSI, STORE LAYOUT DAN SELF SERVICE YANG MEMPENGARUHI KONSUMEN DALAM MELAKUKAN IMPULSE BUYING (Studi pada konsumen supermarket Loka Malang City Point kota Malang)
}

\author{
Cesarika Pradini \\ Department of Management FEB UMM \\ E-mail: cesa1707@gmail.com
}

\begin{abstract}
The purpose of this research are 1 ) to find out whether the promotion, store layouts, and self service significantly influence toward impulse buying 2 ) to find out whether the promotion, store layouts, and self service influence simultaneously significant toward impulse buying. This research uses quantitative approach, the method whis is used in this research is accidental sampling; determine sample based on coincidence. It can be said that anyone who coincidentally meet the researcher and if the persons is suitable as data source, the researcher will ask the persons to fill out questionnaire which is later it will be use as sample. The population in this research was the consumers who shopped in Loka Malang City Point with the total of 100 respondents. The instrument for the analysis is research instrument tests which are validity and reliability test by using heteroscedasticity test, multicollinearity test, and linearity test. After that continued with multiple regression analysis. This research has a purpose to analyze the independent variable $(x)$ in this case is the independent variable that affects to impulse buying, the variable among others is the variable sale, store layout, and self service. After all the research instrument testing, the last thing to do is hypothesis testing used t-test and f-test. Based on this research it can be concluded as follows: variable promotion, store layout, and self service significantly influence impulse buying in partial and simultaneous.
\end{abstract}

Keywords: Sale, store layout, self service, dan impulse buying

\section{PENDAHULUAN}

Bisnis ritel atau eceran telah menjamur dibanyak tempat di Indonesia, bisa dibilang bisnis ritel sudah sangat pesat dan tentu banyak pesaing. Kemajuan bisnis ritel tersebut diakibatkan karena adanya perkembangan usaha manufaktur serta peluang pasar yang cukup terbuka yang disebabkan oleh dampak dari lajunya kondisi ekonomi. Salah satu penyebab perkembangan ekonomi tersebut adalah keputusan pembelian konsumen, ada beberapa macam keputusan pembelian salah satunya adalah Impulse Buying.

Impulse buying dapat dijelaskan sebagai pembelian yang tidak direncanakan sebelumnya. Karakteristik dari pembelian secara impulsif, yaitu pengambilan keputusan pembelian yang relatif cepat dan prasangka subjektif yang mendukung kepemilikan langsung (Abdolvand, 2011). Impulse Buying 
banyak terjadi pada supermarket, salah satunya supermarket Loka Malang City Point kota Malang.

Supermarket Loka dibawah naungan PT. Mahadana Hadiya (Mahadya). Loka berupaya menawarkan sebuah konsep berbelanja yang baru dan unik bagi konsumen Indonesia. Hal ini sejalan dengan slogan yang diusungnya, yaitu "Engage, Experience, Every Day". Konsep dan slogan tersebut kemudian dituangkan dalam segala aspek penampilan Loka.

Dari sisi desain interior, Loka dirancang secara modern dan elegan dengan konsep shop in shop. Dalam hal tersebut shop in shop menjadi pembeda Loka di pasar ritel. Terdapat toko di dalam sebuah toko besar, konsep ini terlihat dari toko khusus, seperti produk daging yang diberi nama D'butcher, untuk daging babi ada The Pork Shop, sedangkan untuk ikan dan produk laut ada Fishermans Catch.

Loka juga menghadirkan tempat istirahat yang cukup menyenangkan untuk pengunjung supermarket tersebut. Loka memastikan tidak akan ada salah cetak karena semua harga diatur langsung dari pusat dengan teknologi electronic shelf label. Sebagian besar label yang terdapat di Loka adalah paperless. Harga akan tercantum di sebuah alat elektronik dan semuanya diatur langsung dari pusat. Dengan sistem ini, harga yang dipajang akan selalu sama dengan kasir. Di sisi lain promosi pada supermarket Loka memberikan kemudahan dalam menyampaikan informasi melalui website. Loka juga memiliki katalog yang diterbitkan bulanan, mingguan, dan dalam kurun waktu tertentu, kemudian Loka menyediakan member card untuk pelanggan setia.

\section{TINJAUAN PUSTAKA}

Keputusan pembelian konsumen adalah membeli merek yang paling disukai dari berbagai alternatif yang ada, tetapi dua faktor bisa berada antara niat pembelian dan keputusan pembelian. Faktor pertama adalah sikap orang lain dan faktor yang kedua adalah faktor situasional. Oleh karena itu, preferensi dan niat pembelian tidak selalu menghasilkan pembelian yang aktual (Kotler dan Amstrong, 2008). Sedangkan menurut Kotler dan Amstrong (2008)

Keputusan pembelian adalah proses keputusan pembeli tentang merek mana yang dibeli. Keputusan pembelian merupakan kegiatan individu yang secara langsung terlibat dalam pengambilan keputusan untuk melakukan pembelian terhadap produk yang ditawarkan oleh penjual. Analisis suatu proses pembelian merupakan suatu rangkaian tahapan yang diambil oleh seorang konsumen. Adapun model yang penulis kemukakan disini adalah model yang dikemukakan oleh Kotler dan keller (2008:235) yang akan ditunjukkan oleh Gambar 1:

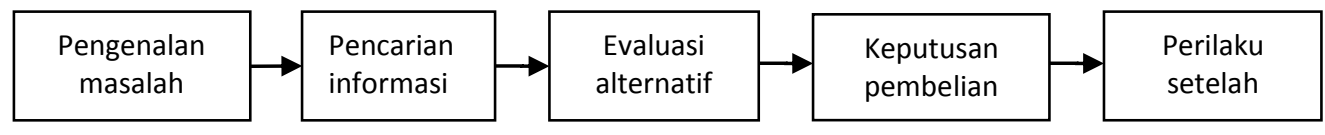

Gambar 1. Tahap Proses Pengambilan Keputusan 
Impulse Buying yaitu pembelian yang dilakukan tanpa ada rencana atau niat terlebih dahulu. Produk-produk impulse buying kebanyakan produk dengan harga murah, kemasan yang unik. Strategi ini diterapkan untuk meningkat keinginan belanja konsumen sehingga melebihi kegiatan belanja dari yang direncakan semula. Impulse buying menjelaskan suatu prilaku yang tidak terencana, tidak beraturan, dan spontanitas. Sebagai contoh pembelian impulsif terjadi ketika adanya dorongan untuk membeli sesuatu selain menghabiskan waktu dan perhatian untuk membeli barang ketika masuk toko (Baumeister, 2002 : 10, Ria Arifianti, 2010).

Perusahaan

menerapkan

promosi sebagai srategi pemasarannya, dengan promosi maka produk atau jasa yang dijual oleh perusahaan akan cepat dikenal oleh masyarakat luas. Dalam melakukan promosi perusahaan selalu berusaha menciptakan promosi yang unik dan semenarik mungkin. Tujuan utama dari promosi adalah modifikasi tingkah laku konsumen, menginformasikan, mempengaruhi, dan membujuk, serta mengingatkan konsumen sasaran tentang perusahaan dan produk atau jasa yang dijualnya (Swatha dan Irawan, 2005).

Seiring dengan berubahnya cara pandang konsumen terhadap belanja saat ini sudah tidak lagi menjadi tempat mencari kebutuhan saja tetapi juga berbelanja adalah salah satu cara untuk menghilangkan penat atau stres. Pada saat itulah sering terjadi impulse buying, sehingga pada saat ini perusahaan berlomba-lomba membuat usahanya dibanjiri konsumen. Salah satu contoh daya tarik konsumen terhadap suatu tempat adalah store layout. Kelengkapan barang, harga yang menarik, tata letak barang yang rapi, kebersihan dan faktor lain dapat memungkinkan konsumen datang secara rutin untuk memenuhi kebutuhan mereka atau hanya untuk sekedar berkunjung. Store layout merupakan rencana untuk menentukan lokasi tertentu dan pengaturan dari lorong didalam toko yang cukup lebar dan memudahkan orang untuk berlalulalang, serta fasilitas toko seperti ruang ganti yang baik dan nyaman (Berman dan Evan, 2004).

Sistem self service diterapkan pada bisnis ritel yang bermanfaat untuk memberi kenyamanan kepada setiap pelanggan terutama dalam dunia ritel. Sistem self service memiliki tujuan agar konsumen merasa nyaman dan bebas dalam memilih barang kebutuhannya. Self service adalah salah satu solusi dari permasalahan harga dan self service bagi perusahaan dapat menekan biaya operasional, misalnya dalam hal gaji pegawai (Swastha, 2000).

Supermarket atau pasar modern adalah tempat yang menyediakan kebutuhan konsumen, produk yang disediakan oleh supermarket adalah produk pilihan yang bersih dan higienis dibanding dengan pasar tradisional. Tujuan supermarket adalah untuk memudahkam masyarakat untuk memenuhi kebutuhannya, baik kebutuhan harian, bulanan, atau dalam waktu tertentu. Produk yang dijual di supermarket adalah produk yang terpilih, higienis, dan fresh sehingga 
harganya pun lebih mahal dan tidak bisa ditawar. Berdasarkan paparan tersebut, maka kerangka konseptual penelitian seperti Gambar 2:

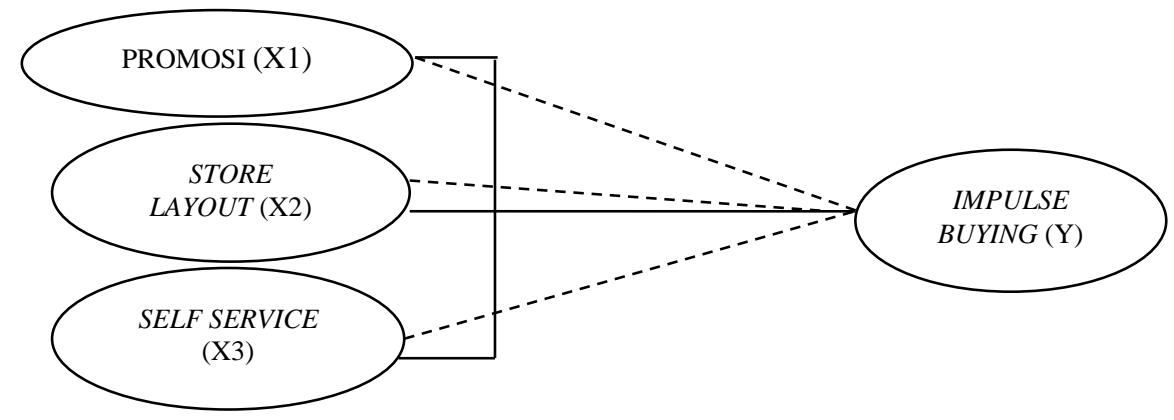

Gambar 2. Kerangka Konseptual Penelitian

Maka hipotesis dari penelitian ini adalah: H1: Semakin menarik promosi yang dilakukan oleh supermarket Loka, maka impulse buying akan mengalami kenaikan. H2: Semakin menarik store layout pada supermarket Loka, maka impulse buying akan mengalami kenaikan. H3: Semakin bebas konsumen dalam berbelanja di supermarket Loka, maka impulse buying akan mengalami kenaikan. $\mathrm{H} 4$ :Semakin menarik promosi, store layout dan semakin bebas konsumen dalam berbelanja di supermarket Loka, maka impulse buying akan meningkat.

\section{METODE PENELITIAN}

Penelitian dilakukan di supermarket Loka Malang City Point kota Malang. Jenis penelitian yang digunakan adalah penelitian deskriptif dengan pendekatan kuntitatif. Dalam penelitian ini yang menjadi populasi adalah konsumen yang berbelanja di supermarket Loka Malang City Point kota Malang. Sampel dalam penelitian ini adalah konsumen yang ditemui secara acak oleh peneliti supermarket Loka Malang City Point kota Malang.
Populasi yang cukup besar tidak memungkinkan untuk diteliti secara keseluruhan, maka diambil 100 sampel untuk penelitian. Menurut Fraenkel dan Wallen dalam Widayat (2004) yang menyatakan bahwa besarnya sampel minimum untuk penelitian yang bersifat deskriptif yaitu sebanyak 100 responden. Teknik dalam pengambilan sampel dalam penelitian ini menggunakan nonprobability sampling dan dilanjutkan dengan teknik accidental sampling yaitu, teknik penentuan sampel berdasarkan kebetulan, yaitu siapa saja yang secara kebetulan bertemu dengan peneliti dapat digunakan sebagai sampel, jika orang yang ditemui tersebut dianggap cocok sebagai sumber data.

Definisi operasional variabel dalam penelitian ini adalah sebagai berikut. Promosi merupakan kegiatan untuk menginformasikan produk atau jasa, memperkenalkan produk atau jasa, dan membujuk konsumen untuk membeli. Indikator meliputi diskon, hadiah, dan sales promotion girl. Store layout merupakan pengaturan dari jalan di dalam toko yang cukup lebar dan memudahkan orang untuk berlalu 
lalang serta penataan rak-rak produk yang rapi. Indikator meliputi pengelompokan jenis produk, desain dalam toko menarik, jarak antar rak luas sehingga arus lalu lintas konsumen leluasa, dan kelengkapan jenis produk.

Self service merupakan sistem pelayanan mandiri yang dimana konsumen dapat memilih dan mencari sendiri barang yang dibutuhkan. Self service bagi perusahaan dapat menekan biaya operasional, misalkan dalam hal gaji pegawai. Indikator meliputi self selection dimana konsumen bebas memilih sendiri barang yang dicari, dan self service technology memudahkan kosumen dalam melakukan transaksi pembayaran (mesin EDC).

Impulse buying adalah pembelanjaan tanpa direncanakan sebelumnya yang dimana konsumen tidak memikirkan resiko terhadap produk yang dibelinya secara spontan. Indikator meliputi Pembelian secara spontan atau secara tiba-tiba tanpa berpikir resiko yang akan terjadi, dan barang pengganti yang artinya membeli barang pengganti tetapi sesuai dengan kebutuhan konsumen.

\section{HASIL PENELITIAN DAN PEMBAHASAN}

Tabel 1. menunjukkan hasil uji validitas instrumen penelitian. Dari tabel tersebut dapat disimpulkan bahwa semua instrumen dari variabeldalam penelitian ini yaitu, promosi, store layout, self service dan impulse buying telah valid, karena semua item-item pernyataan yang mengukur variabel diatas memiliki koefisien korelasi yang lebih besar dari $r_{\text {table }}=0,197$ (nilai $\mathrm{r}$ tabel untuk $\mathrm{n}=100$ ), sehingga semua item tersebut adalah valid atau semua item pada penelitian ini layak digunakan untuk mengukur variabel dalam penelitian ini.

Tabel 1. Hasil Uji Validitas

\begin{tabular}{|c|c|c|c|c|}
\hline Variabel & Item & Koefisien Korelasi & $\mathrm{r}$ Tabel & Keterangan \\
\hline \multirow{7}{*}{ Promosi } & $\mathrm{X}_{1.1}$ & 0,608 & 0,197 & Valid \\
\hline & $\mathrm{X}_{1.2}$ & 0,686 & 0,197 & Valid \\
\hline & $\mathrm{X}_{1.3}$ & 0,697 & 0,197 & Valid \\
\hline & $\mathrm{X}_{1.4}$ & 0,657 & 0,197 & Valid \\
\hline & $\mathrm{X}_{1.5}$ & 0,674 & 0,197 & Valid \\
\hline & $\mathrm{X}_{2.1}$ & 0,615 & 0,197 & Valid \\
\hline & $\mathrm{X}_{2.2}$ & 0,609 & 0,197 & Valid \\
\hline \multirow{3}{*}{ Store Layout } & $\mathrm{X}_{2.3}$ & 0,620 & 0,197 & Valid \\
\hline & $\mathrm{X}_{2.4}$ & 0,606 & 0,197 & Valid \\
\hline & $\mathrm{X}_{2.5}$ & 0,613 & 0,197 & Valid \\
\hline \multirow{4}{*}{ Self Service } & $\mathrm{X}_{3.1}$ & 0,699 & 0,197 & Valid \\
\hline & $X_{3.2}$ & 0,670 & 0,197 & Valid \\
\hline & $\mathrm{X}_{3.3}$ & 0,723 & 0,197 & Valid \\
\hline & $\mathrm{Y}_{1.1}$ & 0,674 & 0,197 & Valid \\
\hline \multirow{2}{*}{$\begin{array}{l}\text { Impulse } \\
\text { Buying }\end{array}$} & $\mathrm{Y}_{1.2}$ & 0,627 & 0,197 & Valid \\
\hline & $\mathrm{Y}_{1.3}$ & 0,655 & 0,197 & Valid \\
\hline
\end{tabular}

reliabilitas, menggambarkan bahwa Cronbach Alpha yang cukup besar 
yaitu diatas 0,60 sehingga dapat dikatakan semua konsep pengukur masing-masing variabel dari kuisioner adalah reliabel sehingga untuk selanjutnya item-item pada masing-masing konsep variabel tersebut layak digunkan sebagai alat pengukur.

Tabel 2. Hasil Uji Reliabilitas

\begin{tabular}{ccc}
\hline Variabel & Cronbach Alpha & Status \\
\hline Promosi $(\mathrm{X} 1)$ & 0,846 & Reliabel \\
Store Layout $(\mathrm{X} 2)$ & 0,819 & Reliabel \\
Self Service $(\mathrm{X} 3)$ & 0,835 & Reliabel \\
Impulse Buying $(\mathrm{X} 4)$ & 0,804 & Reliabel \\
\hline
\end{tabular}

Persamaan linier berganda digunakan untuk mengetahui bentuk hubungan antara variabel bebas yaitu, promosi
(X1), store layout (X2), self service (X3), dengan variabel terikat impulse buying (Y).

Tabel 3. Tabel Analisis Linier Berganda

\begin{tabular}{cccccc}
\hline \multirow{2}{*}{ Variabel } & $\begin{array}{c}\text { Unstandardized Coefficients }(B) \\
\text { B }\end{array}$ & $\begin{array}{c}\text { Standardized } \\
\text { Coefficients }(\beta)\end{array}$ & t hitung & Sig. \\
\hline Constant & $-0,212$ & 1,371 & & $-0,055$ & 0,878 \\
Promosi (X1) & 0,203 & 0,057 & 0,290 & 3,565 & 0,001 \\
Store Layout (X2) & 0,216 & 0,057 & 0,310 & 3,821 & 0,000 \\
Self Service (X3) & 0,329 & 0,078 & 0,335 & 4,235 & 0,000 \\
\hline
\end{tabular}

Variabel dependen pada regresi ini adalah Impulse Buying (Y) dan variabel independennya adalah Promosi (X1), Store Layout (X2) dan Self Service (X3). Model persamaan regresi berdasarkan hasil analisis di atas adalah:

$$
\begin{gathered}
Y=-0,212+0,203 X_{1}+0,216 X_{2}+ \\
0,329 X_{3}+e
\end{gathered}
$$

Hasil uji t dilakukan untuk mengetahui pengaruh secara parsial antara variabel bebas terhadap variabel terikat.

Tabel 4. Hasil Uji f

\begin{tabular}{ccccc}
\hline Variabel & $\mathrm{t}_{\text {hitung }}$ & $\mathrm{t}_{\text {tabel }}$ & Sig. & Keterangan \\
\hline Promosi $(\mathrm{X} 1)$ & 3,565 & 1,985 & 0,001 & Hipotesis Diterima \\
Store Layout $(\mathrm{X} 2)$ & 3,821 & 1,985 & 0,000 & Hipotesis Diterima \\
Self Service $(\mathrm{X} 3)$ & 4,235 & 1,985 & 0,000 & Hipotesis Diterima \\
\hline
\end{tabular}

Dari Tabel 4. Dapat diketahui bahwa hipotesis pertama, yaitu pengaruh Promosi terhadap Impulse Buying memeroleh nilai $t_{\text {hitung }}(3,565)$ $>\mathrm{t}_{\text {tabel }}(1,985)$ dan nilai signifikansi $(0,001)<0,05$ sehingga hipotesis pertama $\left(\mathrm{H}_{1}\right)$ diterima. Artinya, variabel Promosi secara parsial berpengaruh signifikan terhadap Impulse Buying, Hipotesis kedua yaitu pengaruh Store Layout terhadap Impulse Buying. Berdasarkan hasil 
analisis diperoleh nilai $t_{\text {hitung }}(3,821)$ $>\mathrm{t}_{\text {tabel }}(1,985)$ dan nilai signifikansi $(0,000)<0,05$ sehingga hipotesis kedua $\left(\mathrm{H}_{2}\right)$ diterima. Artinya, Store Layout secara parsial berpengaruh signifikan terhadap Impulse Buying.

Hipotesis ketiga yaitu pengaruh

Self Service terhadap Impulse Buying. Berdasarkan hasil analisis diperoleh nilai $t_{\text {hitung }}(4,235)>t_{\text {tabel }}$ $(1,985)$ dan nilai signifikansi $(0,000)$ $<0,05$ sehingga hipotesis ketiga $\left(\mathrm{H}_{3}\right)$ diterima. Artinya, Self Service secara parsial berpengaruh signifikan terhadap Impulse Buying. Berdasarkan tabel di atas, diperoleh $F_{\text {hitung sebesar 29,078 dengan nilai }}$ signifikansi sebesar 0,000. Nilai Ftabel dengan derajat bebas 3 dan 96 sebesar 2,699. Karena nilai F-hitung $>$ F-tabel atau nilai signifikansi<taraf nyata 0,05 maka hipotesis ke empat diterima. Artinya, variabel Promosi, Store Layout dan Self Service secara simultan berpengaruh signifikan terhadap Impulse Buying.

Hasil pengujian hipotesis 1 mendapatkan bahwa promosi memiliki pengaruh positif terhadap impulse buying. Hal ini berarti bahwa promosi yang tinggi akan meningkatkan impulse buying. Hasil ini menjelaskan bahwa promosi menjadi tambahan referensi bagi perusahaan dan menjadi pertimbangan bagi perusahaan untuk meningkatkan konsumen. Promosi yang menarik akan menjadi keputusan bagi konsumen untuk tetap setia pada suatu perusahaan tersebut.

\begin{tabular}{llr}
\multicolumn{1}{c}{ Hasil } & penelitian & ini \\
mendapatkan & bahwa & suatu \\
perusahaan harus & memiliki & strategi \\
untuk memikat & pelanggan & dan \\
mempertahankan & pelanggan salah
\end{tabular}

satunya dengan melakukan promosi yang menarik, dalam hal ini konsumen atau pelanggan yang sebagian besarnya wiraswasta ini mengharapkan promosi yang disampaikan perusahaan kepada pelanggan sesuai dengan keistimewaan produk yang ada, harga yang relatif terjangkau dan harga yang sudah sesuai dengan manfaat produk.

Hasil penelitian ini mendukung penelitian yang dilakukan oleh Ria Arifianti, 2013 yang mengatakan bahwa promosi penjualan mempunyai pengaruh terhadap impulse buying apabila promosi dilakukan sesering atau dilaksanakan dengan baik maka akan meningkatkan daya beli konsumen dalam hal ini adalah impulse buying.

Pengujian hipotesis 2 menunjukkan adanya pengaruh yang positif dan signifikan pada variabel store layout pada supermarket Loka. Hal ini menunjukkan bahwa penilaian yang baik mengenai store layout terhadap impulse buying. Hal ini menjelaskan bahwa pada umumnya responden akan memperhitungkan store layout yang rapi, penataan produk pada rak tinggi yang mudah dijangkau dan bersih sehingga menimbulkan rasa nyaman saat berbelanja dan membuat konsumen merasa betah berlamalama berada didalam sebuah supermarket.

Hasil penelitian ini mendukung penelitian yang dilakukan oleh Deswitha, 2015 yang mengatakan bahwa store layout mempengaruhi konsumen saat berbelanja dan membantu konsumen agar mudah dalam mencari kebutuhan, store layout meningkatkan minat beli 
konsumen yang dalam hal ini adalah impulse buying.

Hasil hipotesis 3 mendapatkan bahwa self service berpengaruh positif dan signifikan terhadap impulse buying. Hal ini menunjukkan bahwa hasil penilaian yang baik mengenai sistem self service pada bisnis ritel seperti supermarket. Hasil dari penelitian ini mejelaskan bahwa kosumen membutuhkan kebebasan dan kenyamanan saat berbelanja.

Dalam penelitian ini menunjukkan bahwa kebebasan dan kenyamanan konsumen saat berbelanja dapat meningkatkan minat beli konsumen sehingga sering kali terjadi impulse buying. Kemudian dari hasil uji $F$ memperlihatkan bahwa pengaruh secara bersamaan atau simultan dari seluruh variabel independen (promosi, store layout, dan self service) terhadap impulse buying menunjukkan hasil yang signifikan.

\section{SIMPULAN}

Berdasarkan hasil dari pembahasan ini dapat disimpulkan sebagai berikut: Promosi berpengaruh positif dan signifikan terhadap impulse buying. Store layout berpengaruh positif dan signifikan terhadap impulse buying, Self service berpengaruh positif dan signifikan terhadap impulse buying, Promosi, store layout, dan self service berpengaruh positif dan signifikan terhadap impulse buying.

\section{DAFTAR PUSTAKA}

Abdolvand, 2011, The Effects of Situational and Individual Factors on Impulse Buying: World Applied Sciences, Journal of Marketing, 13 (9): 2108-2117.
Baumeister, Roy F. 2002, Yielding to Temptation: Self-Control Failure, Impulsive behavior. Analisis Impulse Buying pada Hypermarket kota Bandung. http://pustaka.unpad.ac.id/.

Diakses pada 29 Februari 2016

Berman dan Evan. 2004. Retail Management, Penerbit Andi: Yogyakarta.

Buedincho, P. 2003. Impulse Purchasing: Trend or Trait, Jurnal Manajemen Pemasaran Petra Vol.2, No. 1, 2014, Hal. 1-8

Buchari, A. 2005. Manajemen Pemasaran dan Pemasaran Jasa. Bandung: Alfabeta.

Dawson, S., \& Kim, M. 2009. External and internal trigger cues of impulse buying online: International, Journal of Marketing Studies Vol. 5, No. 3; 2013

Fatna, Ayni. 2011. Belanja Impulsif. http://aynipsychology.blogspot. co.id/. Diakses pada tanggal 2 Februari 2016

Ferdinand, A., 2006. Metode Penelitian Manajemen: Pedoman Penelitian untuk skripsi, Tesis dan Disertai Ilmu Manajemen. Semarang: Universitas Diponegoro.

Ghozali, Imam. 2005. Aplikasi Analisis Multivariate Dengan Program SPSS 19 . Semarang: Badan Penerbit Universitas Diponegoro.

Hansen, Kare dan Olsen, Svein Ottar., 2008. Impulsive Buying and Store Patronage: The Role of Convenience Orientation and Time Pressure, Jurnal Ultima Management Vol. 3, No. $1 / 2011$. 
Harmangcioglu, N., Finney, R. Z., \& Joseph, M., 2009. Impulse purchase of new product: an empirical analysis. International, Journal of Marketing Studies Vol. 5, No. 3; 2013.

Hawkins, D., Mothersbough, D., dan Best, R., 2007. Consumer Behaviour ; Building Marketing Strategy. 10th Edition, McGraw Hill Irvin.

Howard, M., and Worboys, C., 2003. Self Service-Contradiction in term or Customer-led Choice?, Journal of Consumer Behaviour, 2 (4) : 382-392.

Koo, D.M., 2003, Inter- relationships among stores images, stores satisfaction, and store loyalty among Korea discount retail patrons, Jurnal Manajemen Pemasaran Vol. 6, No. 1, April 2011: 8-21.

Kotler, Philip., .2002. Manajemen Pemasaran di Indonesia, Analisis, Perencanaan, Implementasi dan Pengendalian. Jakarta: Salemba Empat.

2008. Prinsip-prinsip Pemasaran Di Indonesia.Edisi Keduabelas. Jilid 1, Jurnal e-maksi Harapan Vol. 1, No. 1, Februari 2013.

2008. Prinsip-Prinsip Pemasaran. Edisi Keduabelas. Jilid Pertama, Jurnal EMBA Vol. 1, No. 4, Desember 2013, Hal. 95-104.

2000. Manajemen Pemasaran. PT. Prenhallindo: Jakarta.

Nugroho, Setiadi., 2008. Perilaku Konsumen. Cetakan Ketiga. Kencana. Jakarta. Jurnal
EMBA Vol. 1, No. 4, Desember 2013, Hal. 95-104.

Meutter, L. M., Ostrom, A.L., Roundtree, R. L., and Bitner, M. J., 2000. Self Service Technology: Understanding Customer Satisfaction with Technology-Based Service Encounter, Journal of Marketing, 64 (3) 50-64.

Samuel, H., 2005. Respons Lingkungan Berbelanja Sebagai Stimulus Pembelian Tidak Terencana pada Toko Serba Ada (Toserba), Jurnal Manajemen dan Kewirausahaan Vol. 7 No. 2, pp. 152-170.

Sarjono dan Julianita., 2011. SPSS vs LISREL Sebuah Pengantar Aplikasi Untuk Riset. Salemba Empat: Jakarta. file:///C:/Users/User/Download s/671-1290-1-SM.pdf. Diakses pada 2 Januari 2016.

Scott W. VanderStoep and Deirdre J. Johnston., 2009. Research Methods for Everyday Life: Blending Qualitative and Quantitative Approaches. http://setabasri01.blogspot.co.i d/2012/04/metodepenelitian.html.

Diakses pada tanggal 2 Februari 2016

Sugiyono. 2004. Metode Penelitian Bisnis: Penerbit CV. Alfabeta: Bandung

2006, Statistika Untuk Penelitian, Cetakan Ketujuh, Alfabeta: Bandung.

2013. metode penelitian pendidikan pendekatan kuantitatif, kualitatif dan R \& D, Bandung: Cv. Alfa Beta, 2010. https://afidburhanuddin.wordpr 
ess.com._Diakses pada tanggal 3 Januari 2016.

Swastha, Basu., dan Irawan., 2005.

Manajemen

Pemasaran

Modern, Yogyakarta: Liberty, Jurnal Ilmiah STIE MDP Vol. 1 No.1.

Ujang Sumarwan., 2004. Perilaku

Konsumen. Ghalia Indonesia.

Bogor, Jurnal Manajemen Vol.10 No.3 April 2013.

Verplanken, Bas., dan Herabadi, Astrid., 2001. Individual Differences in Impulse Buying Tendency: Feeling and No
Thinking, Journal of Ultima Management Vol. 3 No. $1 / 2011$.

Wikipedia. $\quad 2016$. https://id.wikipedia.org/wiki/Pa sar. Diakses pada 31 Januari 2016.

Widayat., 2004. Riset Bisnis Edisi 1. CV. Cahaya Press: Malang.

Wordpress. 2016. Pengertian Marketing.

https://catatanmarketing.wordp ress.com/tag/marketing-

adalah/. Diakses pada 31 Januari 2016 